\title{
GLACIOKARST LANDFORMS IN THE SIERRA DE LOS GRAJOS, BABIA AND LUNA NATURAL PARK (CANTABRIAN MOUNTAINS, NW SPAIN)
}

\author{
GLACIOKRAŠKI RELIEF NA OBMOČJU SIERRA DE LOS GRAJOS \\ V PARKU BABIA IN LUNA (KANTABRIJSKO GOROVJE, \\ SZ ŠPANIJA)
}

\author{
Rosa Blanca GONZÁLEZ-GUTIÉRREZZ, ${ }^{1,}$, Javier SANTOS-GONZÁLEZZ, ${ }^{1 *}$, Amelia GÓMEZ-VILLAR ${ }^{1}$, Eduardo \\ ALONSO-HERRERO², Alipio GARCÍA-DE CELIS ${ }^{3}$, Martín CANO ${ }^{4} \&$ José María REDONDO-VEGA ${ }^{1}$
}

\begin{abstract}
UDC 551.435.4:551.435.8(460.13)

Rosa Blanca González-Gutiérrez, Javier Santos-González, Amelia Gómez-Villar, Eduardo Alonso-Herrero, Alipio García-de Celis, Martín Cano \& José María Redondo-Vega: Glaciokarst landforms in the Siera de los Grajos, Babia and Luna natural park (Cantabrian Mountains, NW Spain)

Landforms resulting from the interaction between paleo-glaciers and karst are studied by using the Sierra de los Grajos (Cantabrian Mountains) as a model. This area contains glacial landforms that have not interested geomorphologists due to their low altitude (Peña Castillo is about $1857 \mathrm{~m}$ a.s.l.), the absence of glacial cirques and the scarcity of large moraines. However, the prevalence of groundwater flow and chemical dissolution has favoured the preservation of glacial landforms. Lateral and frontal moraines show three main glacial stages and other minor glacier stabilization phases, with the paleo-ELA oscillating between 1650 and $1760 \mathrm{~m}$. Moraines are combined with depressions and sinks resulting from subglacial karstic drainage. This convergence of forms and processes is an exception in the Cantabrian Mountains, where postglacial erosion has usually eroded the frontal moraines and the proglacial sediments. In the case of the Sierra de los Grajos, despite the underground drainage and preservation of many glacial deposits on karstic landforms, an outwash-plain was formed. These proglacial sediments and others from non-karstified areas filled the depressions of the preglacial terrain located at their edges. The main glaciokarstic landforms have been mapped and a sedimentological analysis of the outwash plain was made in order to reconstruct the glacial dynamics of this area.

Key words: glaciokarst landforms, glacial geomorphology, karst geomorphology, geomorphological mapping, Cantabrian Mountains.
\end{abstract}

Izvleček UDK 551.435.4:551.435.8(460.13)

Rosa Blanca González-Gutiérrez, Javier Santos-González, Amelia Gómez-Villar, Eduardo Alonso-Herrero, Alipio García-de Celis, Martín Cano \& José María Redondo-Vega: Glaciokraški relief na območju Sierra de los Grajos v parku Babia in luna (Kantabrijsko gorovje, SZ Španija)

$\mathrm{Na}$ območju Sierra de los Grajos (Kantabrijsko gorovje) smo raziskovali relief, ki je $\mathrm{v}$ preteklosti nastal $\mathrm{z}$ medsebojnim vplivanjem kraških in ledeniških procesov. Zaradi nizke nadmorske višine (Peña Castillo je le 1857 m nad morjem) ter odsotnosti velikih moren in krnic to območje geomorfologov do sedaj ni posebej zanimalo. Prav kraški procesi in $\mathrm{z}$ njimi povezano podzemno odtekanje so tu omogočili ohranitev ledeniških oblik. Bočne in čelne morene kažejo na tri glavne faze poledenitev in več manjših faz stabilizacije ledenikov $\mathrm{z}$ ravnovesno mejo (ELA) med 1650 in 1760 m.n.m. Morene so pogosto vezane na kraške globeli. Glaciokraške pojave najdemo le na tem območju Kantabrijskega gorovja, kjer je sicer poledeniška erozija odstranila čelne morene in proglacialne sedimente. Kljub podzemnemu odtoku in ohranitvi številnih ledeniških sedimentov na kraškem reliefu se je na Sierra de los Grajos oblikoval predledeniški vršaj (sander). Proglacialni sedimenti in sedimenti iz nekraških območij so zapolnili globeli v predledeniškem kraškem terenu. Kartiranje glaciokraških reliefnih in analiza sedimentov predledeniških vršajev sta nam omogočila rekonstrukcijo dinamike ledenika na obravnavanem območju.

Ključne besede: glaciokraške reliefne oblike, ledeniška geomorfologija, kraška geomorfologija, geomorfološko kartiranje, Kantabrijsko gorovje, Španija.

\footnotetext{
${ }^{1}$ Department of Geography and Geology, University of León, Campus de Vegazana s/n, 24071, León, Spain, e-mail: blanca. gonzalez@unileon.es,jsango@unileon.es, agomv@unileon.es,jmredv@unileon.es

${ }^{2}$ Upper and Technical School of Agricultural Engineering, University of León (Spain), Avda, Portugal 41, 24071, León, Spain, e-mail: ealoh@unileon.es

${ }^{3}$ Department of Geography, University of Valladolid, Pz. Campus Universitario s/n, 47011, Valladolid, Spain, e-mail: alipio@fyl.uva.es

${ }^{4}$ Department of Geology, University Nacional del Sur, Av. Alem 1253, 8000, Bahía Blanca, Argentina, e-mail: martin.cano@uns.edu.ar

${ }^{\star}$ Corresponding Author

Received/Prejeto: 04.05.2017
} 


\section{INTRODUCTION}

Karst affected by glacial erosion is currently located in some high latitude and high altitude areas. In mountains, the discharge of the melting glaciers occurs through the karstic aquifers. The infiltration of the subglacial water into the karst network reduces overland flow, which modifies the discharges of the pro-glacial streams and the sediments they carry. Therefore, when glacier dynamics converge with a subglacial karst (Žebre \& Stepišnik 2015), a type of landscape that combines the reliefs derived from both processes, named glaciokarst, is generated (Ford 1979; Smart 2004; Žebre \& Stepišnik 2015).During cold stages of the Pleistocene, these dynamics has been common in the calcareous mountains at middle latitudes (Johnson \& Stieglizt 1990; Bodgdan \& Leszek 1999; Goldie 2006; Lepirica 2008; Hughes et al. 2010; Telbisz et al. 2011; Adamson et al. 2014; Stepišnik 2014; Žebre \& Stepišnik 2015; Žebre et al. 2016), and also in limestone outcrops of the Cantabrian Mountains were the glacial processes were intense (Jalut et al. 2010; Serrano et al. 2012, 2013; Frochoso et al. 2013; Jiménez-Sánchez et al. 2013; Santos-González et al. 2013a; Gómez-Villar et al. 2015; Rodríguez-Rodríguez et al. 2016; Ruiz-Fernández et al. 2016). However, in lower zones where this association does not occur, karst processes are dominant. This is observed in numerous glacial landforms that hide or adapt to karst forms, like in the Picos de Europa, the highest part of the Cantabrian Mountains, where glaciers occupied the top of a karst massif (González Trueba 2007; Ruiz-Fernández et al. 2016). Glaciers also developed in other areas of calcareous mountains such as the Sierra de los Grajos. However, previous studies have barely highlighted the combination of karst and glacial processes occurring in this range.

By using geomorphological evidences and sedimentological analysis, the main objectives of this research are to establish the influence of glaciation on the karst systems, to identify the main landforms and to highpoint the singular action of glacial systems in the karst areas. The research focused on paleo-glaciers within the Sierra de los Grajos, whose morpho-structural features favoured their development. The calcareous structures of this area where the basis for the creation of a pre-glacial karstic relief characterized by wide areas with gentle slope at a high altitude. The topography favoured the accumulation of ice, in spite of the relatively low altitude of the Sierra de los Grajos. The result is a combination of karstic and glacial processes and landforms.

\section{STUDY AREA}

The Sierra de los Grajos is a part of the Babia and Luna Natural Park, located in the western area of the Cantabrian Mountains, northwestern Spain. It is a karst platform mainly composed of Carboniferous limestone (Rodríguez Pérez 2009) whose dimensions are $6 \mathrm{~km}$ long by $3 \mathrm{~km}$ wide and with elevations below $1900 \mathrm{~m}$ a.s.l. (1857 $\mathrm{m}$ in Peña Castillo) (Fig. 1A). To the south, this platform rises abruptly more than $500 \mathrm{~m}$ above the Vega del Panazal, which is a valley excavated in Carboniferous shales. To the north, the Sierra de los Grajos borders the Vega de Gorgaberos, a closed karstic depression around $1650 \mathrm{~m}$ (García de Celis 1997). In general, Paleozoic limestone tends to be prone to karstification, although the intensity of karst activity varies depending on the type of limestone facies and structural features. The main massif of the Sierra de los Grajos consists of Carboniferous limestone (Barcaliente and Valdeteja Formations), while in the Vega de Gorgaberos polje, Devonian limestone prevails (Santa Lucía Formation). Between these two zones there is an altitudinal difference of almost $200 \mathrm{~m}$, which can be explained by the different intensity of karstification according to the type of limestone.
Geologically, this area is part of the Fold and Nappe Province, belonging to the Cantabrian Zone (Alonso et al. 2009). The area is included in the Sobia-Bodón Unit and the main tectonic structures that appear are the Pinos and Villafeliz thrusts and the Los Grajos-Valgrande fault (Suárez Rodríguez et al. 1989). These structures are the result of the Variscan tectonics that caused a subvertical disposition of the strata with considerable lithological diversity. From north to south, in less than $4 \mathrm{~km}$ long nine lithological formations have been identified, ranging from the Cambrian to the Upper Carboniferous periods (Fig. 1B). Some of the units are duplicated as a result of the abovementioned faulted anticline (van den Bosch 1969).

This geological structure favoured intense pre-glacial processes that included karstic dissolution. The abundance of limestone outcrops allowed the development of a karst system with a dominant underground circulation versus the surface runoff from adjacent non-calcareous areas. Thus, a high and broad karst platform developed and the favourable conditions to the accumulation of ice during the Pleistocene glaciations were established. 


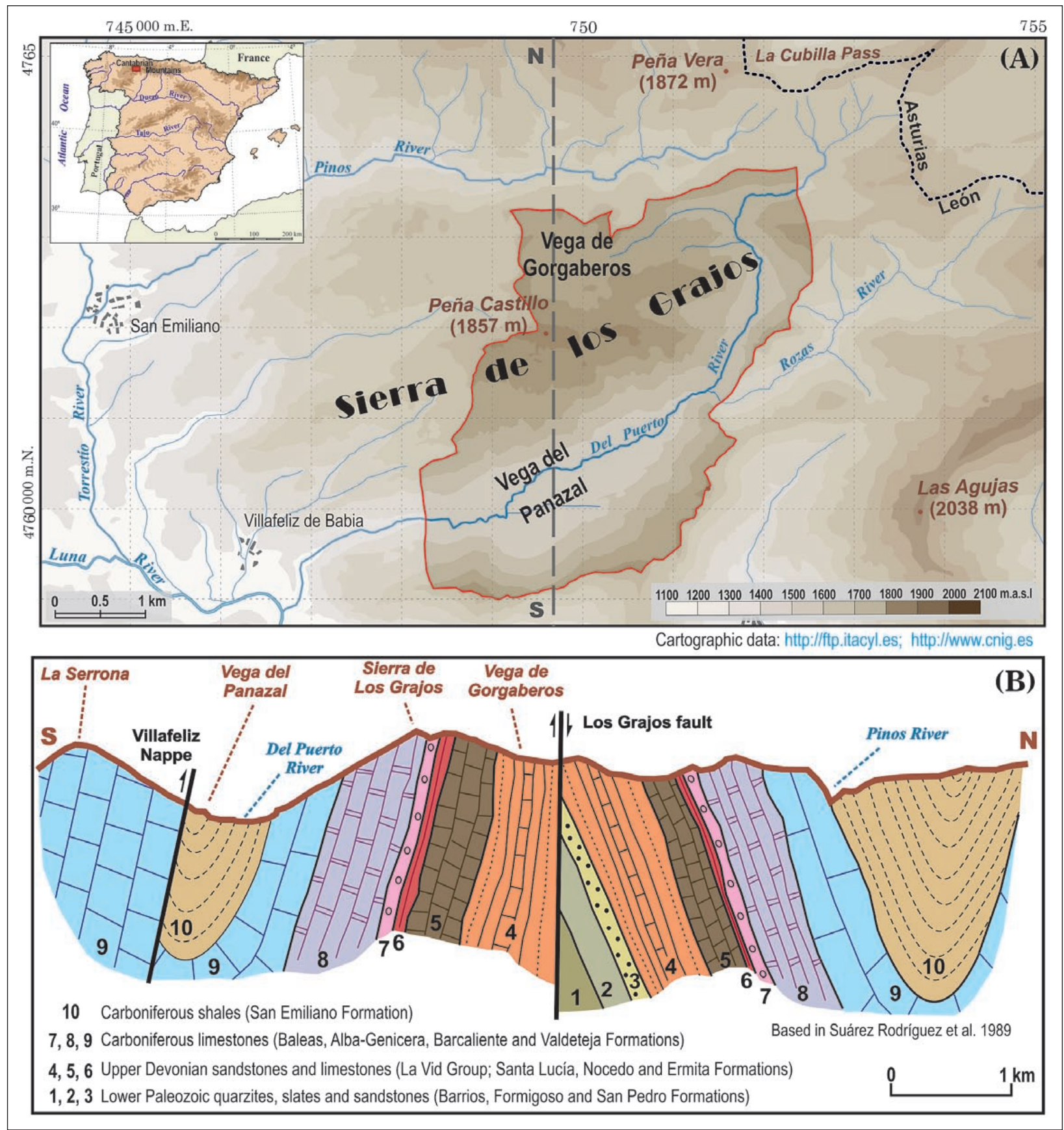

Fig. 1: A - The location of study area. B - The geological section from south to north between La Serrona Peak and La Cubilla Pass.

The first references to glacial and karst elements in the study area are those of García de Celis (1997) in a geomorphological map at scale 1:50,000 next to the Vega de Gorgaberos polje where sinkholes, karstic sinks, moraines and ice diffluences appear. More recently, García de Celis \& Martínez Fernández (2002) indicate the presence of glacial deposits in Del Puerto river valley, near its confluence with the Rozas River, or the fluvioglacial origin of the Vega del Panazal. They also point out the difficulties for a genetic interpretation due to absence of moraines. Another reference is the identification of a frontal moraine in the north face of Peña Castillo by Alonso Herrero et al. (2004). 


\section{MATERIAL AND METHODS}

To achieve the objectives of this study, an extensive field work was carried out in Vega de Gorgaberos, Vega del Panazal and the karst platform of the Sierra de los Grajos. This allowed us to recognize the main karst landforms, the glacial deposits and other fluvioglacial and torrential sediments.

The geomorphological map was designed by using different cartographic sources: the aerial photographs provided by the Spanish Geographic National Institute (IGN, http://www.ign.es) and the Agrarian Technological Institute of the Castilla y León (ITACYL, http://www. itacyl.es/); the orthophotographs from the National Plan of Aerial Orthophotography supplied by Spanish Geographic National Institute; and the digital geologic maps available from the Geological and Mining Institute of Spain (IGME, http://www.igme.es/).

The scales of the analogical aerial photography are 1:33,000 for the American flight of 1956-57, and 1:18,000 for the Inter-ministerial or IRYDA (Institute for Agricultural Reform and Development) flight of 1977-83. The resolution of the digital images is 25 or $50 \mathrm{~cm}$, depending on the year. The American flight is a valuable cartographic source due to the intensive land use at that time. During this period, the study area had a low forest cover, which allows a better identification of glacial and karst landforms than at present. Since then trees and shrubs have extended a lot making difficult the photo interpretation with the recent orthophotos. The Inter-ministerial flight has been used for its high quality and detailed scale, and the high resolution of digital images has been very useful for a detailed mapping of each landform (shape, size, distance).

A preliminary geomorphological map was made with the cartographic and geological information, and also the photointerpretation of the analogical and digital photograms. The software used was the Geographic Information System (GIS) ArcGIS 10.4. The data were verified in the field and some small-sized elements (e.g. erratic boulders, till, polished surfaces) very important in reconstructing the extent and thickness of the paleoglacier in this area were accurately located. Finally, a geomorphological map was performed at the 1:10,000 scale by incorporating all the geomorphological evidences ob- served in the field. For the cartographic base of this map the orthophotograph from 2008 whit a resolution of 25 $\mathrm{cm}$ was used.

Based on geomorphological data we reconstructed past glacial limits during the three main glacial stages and we designed the $50 \mathrm{~m}$ contours of the glacier's surface. A DEM was developed from the contour lines using the GIS software. We then calculated the glacier surface in $50 \mathrm{~m}$ intervals. To estimate the paleo-ELA we used the AABR method (Furbish \& Andrews 1984; Benn \& Gemmell 1997). We applied the Balance Ratio values used by Rea (2009) for mid-latitude maritime glaciers based on contemporary glacier measurements that have a mean of $1.9 \pm 0.81$. Finally, we used the Excel (R) spreadsheet from Osmaston (2005) to estimate the palaeo-ELA. We modified the spreadsheet to use $50 \mathrm{~m}$ intervals.

For the sedimentological analysis, three sampling points have been chosen in the Vega del Panazal, where several sections have been identified (Fig. 2). The first sampling point is located in the southwestern edge of the study area, in a meander of Del Puerto River where a section of more than $10 \mathrm{~m}$ appears. Six sediment samples were collected here for the particle size analysis. The second sampling point is located at the confluence of the Del Puerto River with one of the stream coming from La Serrona Range, and where two samples were collected. Half a kilometre to the northeast, the third sampling point is located. It is on the right bank of the Del Puerto River, near a spring and two sediment samples were picked up. Ten samples in total were taken to be analysed in the laboratory.

The method used to determine the distribution of particle grain size was the mechanical or sieve analysis. Two hundred grams of each sample were placed in a sieve shaker and shaken for 15 minutes. The results of each sieve were weighed and then plotted in a semi-logarithmic curve indicating the cumulative distribution in percent of clay and silt (mud), sand and gravel particles. The results are also represented in a trigon showing the percentage of fine, medium and coarse material of each sample. The particle size scale and the classification of sediments are based on Wentworth scheme (1922) and then modified by Blott and Pye (2012). 


\section{RESULTS}

\section{KARSTIC AND GLACIAL LANDFORMS DURING THE GLACIAL MAXIMUM}

Karst and glacial landforms are dominant in the study area (Fig. 2). The preglacial relief was controlled by the dissolution of limestone, so glaciers developed over karstic landforms. The main area of the Sierra de los Grajos (Peña Castillo) consists of a high flat surface at approximately $1750 \mathrm{~m}$ a.s.l. with features of paleo-surface erosion and underground drainage. This high paleosurface shows sinkholes and subvertical chasms (more than a hundred of these skin points in an area of only 50 hectares) that developed there where two or more lines of weakness (mainly faults) cross in the geological structure (Fig. 3A).

The Vega de Gorgaberos, located to the north of the main massif of the Sierra de los Grajos, is an approximately $1.5 \mathrm{~km} \times 1 \mathrm{~km}$ closed karst depression mainly filled with sediments. This depression has a relatively flat bottom and includes some minor dolines and a ponor. Due to its characteristics and in spite of its small

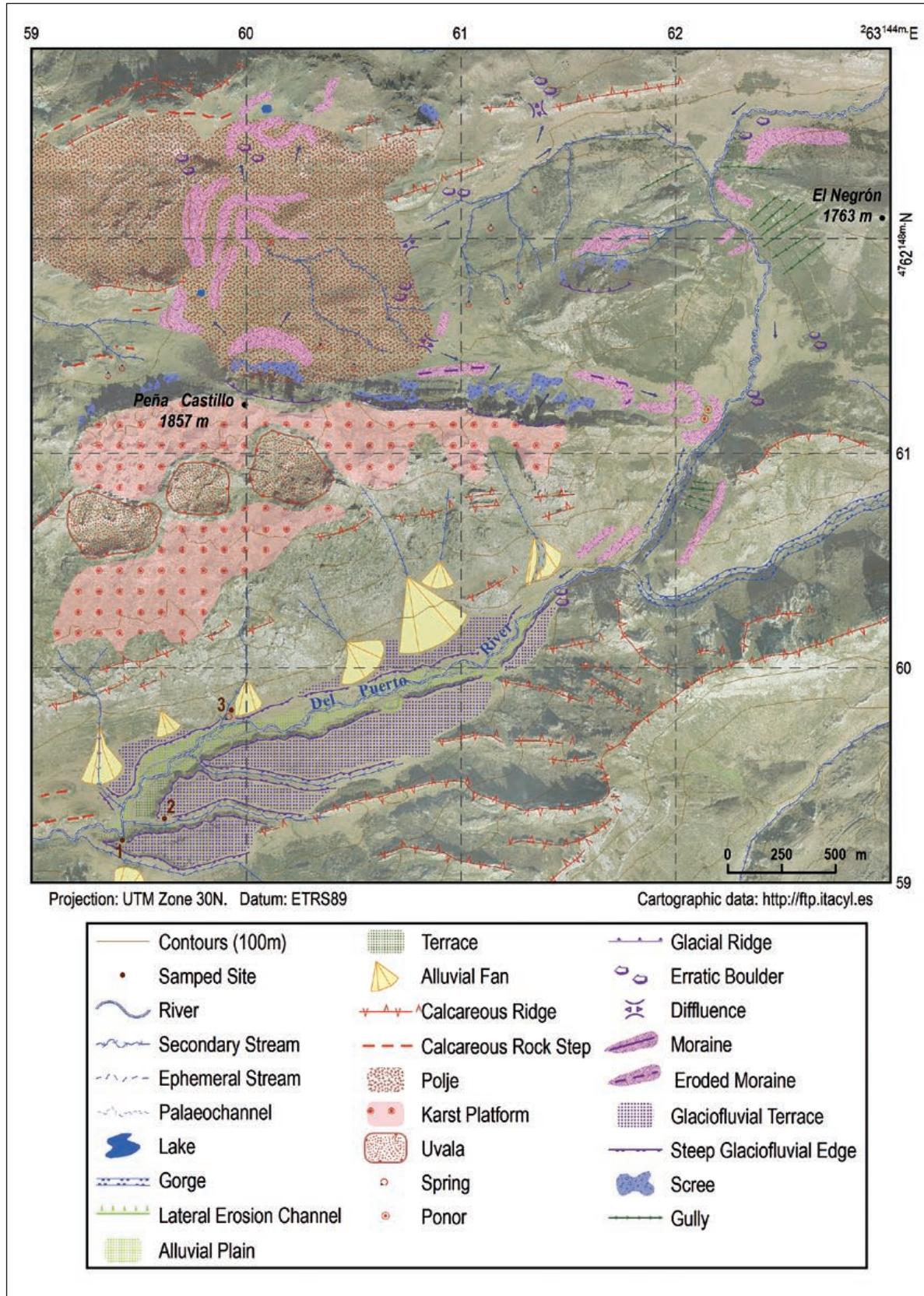

Fig. 2: Geomorphological map the Sierra de los Grajos. 


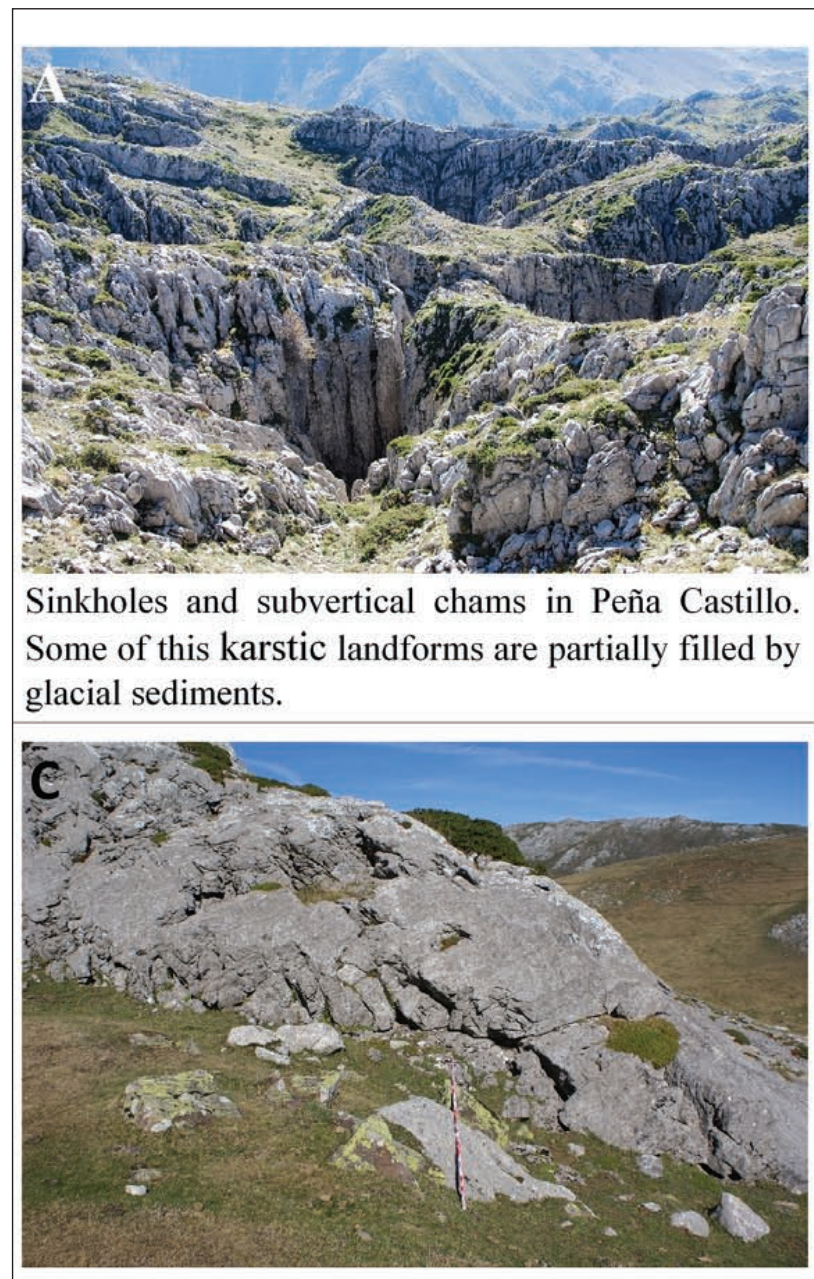

Siliceous erratic boulders (yellow-green lichens) over limestones in Vega de Gorgaberos.

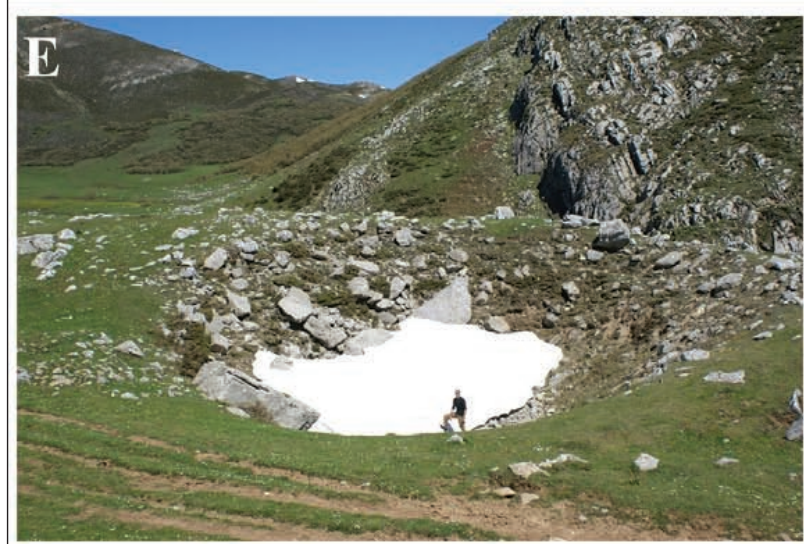

Moraine with sinkhole in Campolamoso area. This sinkholes are related with postglacial karstic dynamics. M. Cano for scale.

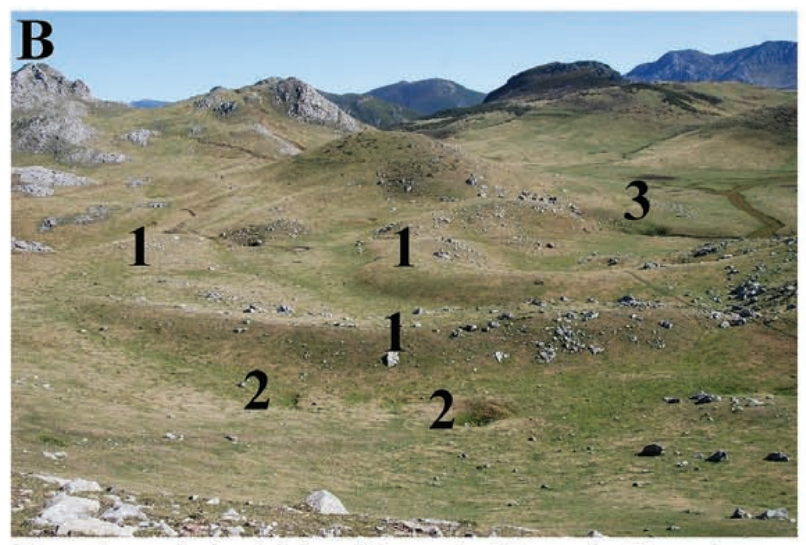

Karstic and glacial landforms in Vega de Gorgaberos polje. Some moraines (1), dolines (2) and a ponor (3) are visible in the image.

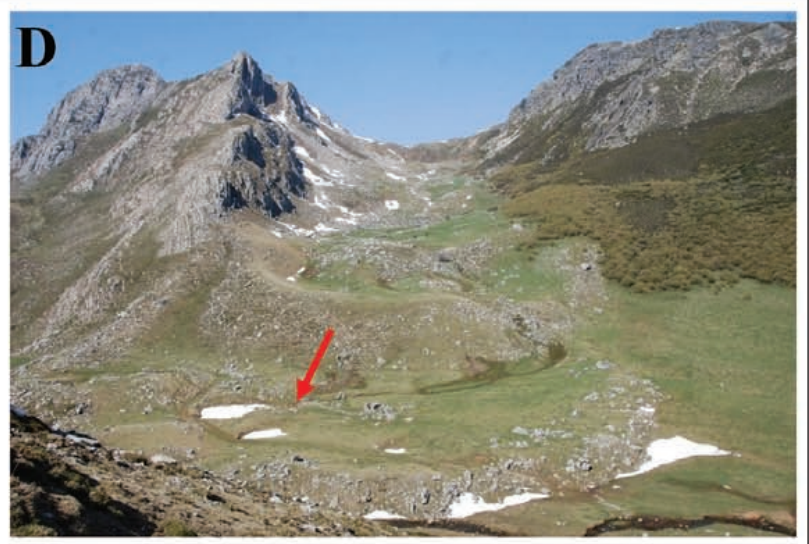

Moraines in Peña Castillo valley. These moraines are very well preserved due to scarce postglacial erosion in a karstic environment. A ponor is also visible in the lower moraine (arrow).

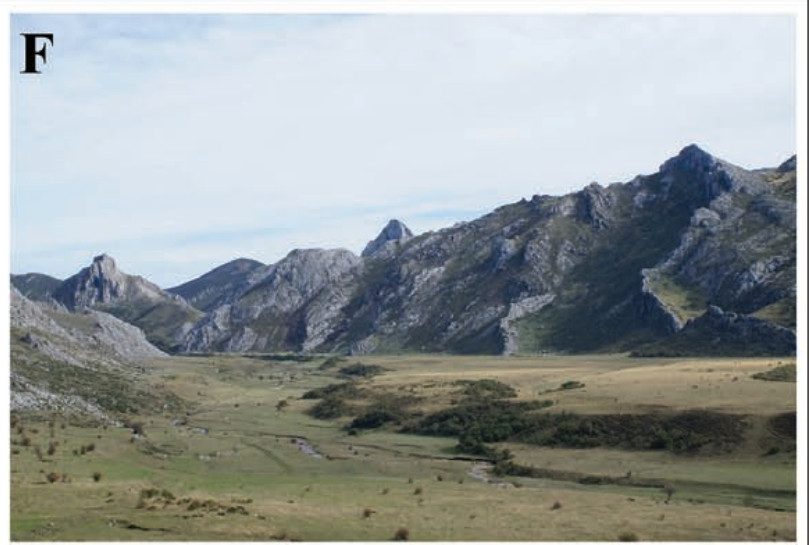

An outwash-plain formed downstream from the front of the main paleo-glacier in Vega del Panazal.

Fig. 3: Main glaciokarstic features in the Sierra de los Grajos. (Photos: J. Santos-González and J. M. Redondo-Vega). 
size compared with other similar landforms (e.g. Gams 2005), we consider it a polje. From a structural point of view, it coincides with a predominantly limestone anticline affecting the Devonian series. There are several moraines inside and in the outer margins of the karst depression. The overlapping of glacial features and processes on karstic terrain has generated a mixed morphology in which the infiltration of runoff into karst and the dissolution of limestone occur in an environment with glacial deposits (Fig. 3B). This morphology has resulted in the formation of glaciokarstic landforms.

In addition to water flowing into the ponors and sinkholes, limestone pavement fields frequently occur (caused by dissolution of the network of diaclases and rock stratification joints), especially on the slopes of the valleys. These limestone pavements act as a form of diffuse absorption of water into the endokarst system. As a result, there are few stream flows that organize the surface runoff, except for some ephemeral ravines coinciding with deposits overlying the calcareous series (Vega de Gorgaberos).

Glacial landforms and deposits are easily recognized in the area. To the west and north, at the perimeter of the Vega de Gorgaberos polje, there is evidence of the limits reached by the ice during the last phase of the glacial maximum. The position of the left lateral moraine, at approximately $1710 \mathrm{~m}$ a.s.l., and the position of part of the polje, at $1641 \mathrm{~m}$ a.s.l., indicate an ice thickness of substantially more than $70 \mathrm{~m}$.

The frontal moraines in the north terminus of the area located above the karst depression (1641 m a.s.l.), and the presence of numerous blocks of sandstone positioned between the limestone ridges that surround the polje to the N (Fig. 3C) also indicate a peak ice thickness of 60 to $70 \mathrm{~m}$. These thicknesses are relatively modest, particularly when compared with other nearby Cantabrian valleys (Jalut et al. 2010; Santos-González et al. 2013a; Serrano et al. 2013; Rodríguez-Rodríguez et al. 2015), but they are sufficient to demonstrate the existence of the paleo-glacial dynamics in the area and their influence on the morphology.

From the Vega de Gorgaberos polje, a glacial tongue flowed to the north towards the Pinos valley, as evidenced by the abundant remnants of the siliceous boulders deposited in the limestone hills in the area. The main paleo-glacier moved to the northeast and joined with a glacier flowing from the divide (Puerto de la $\mathrm{Cu}$ billa). From the confluence of the two glacier tongues, it

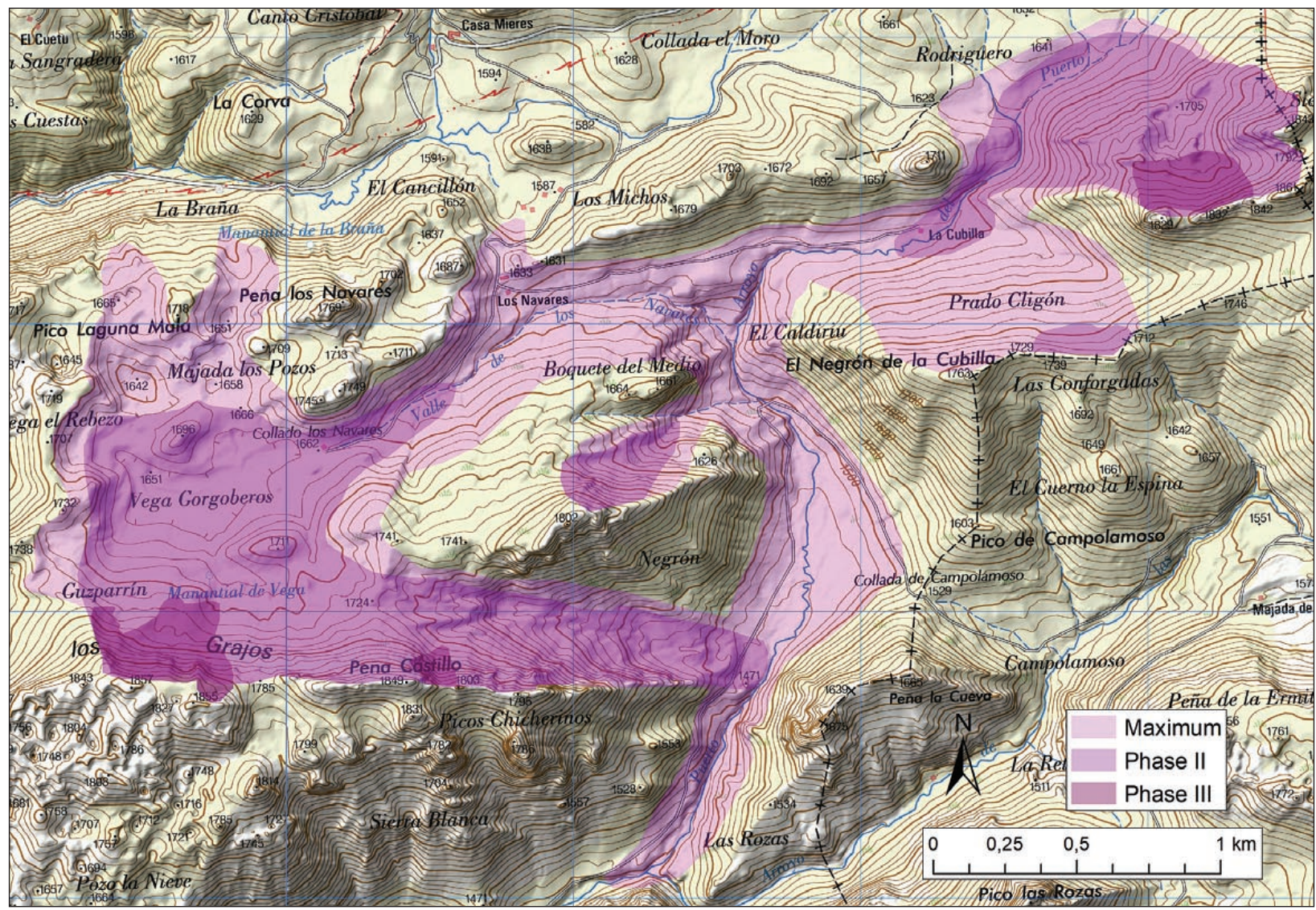

Fig. 4: Paleo-glacier reconstruction during the main three glacial stages in the Sierra de los Grajos. 
Tab. 1: Equilibrium line altitudes during different glacial stages in the Sierra de los Grajos.

\begin{tabular}{l|l|l}
\hline Glacial stage & Glacier & ELA \\
\hline Phase I & Sierra de los Grajos & $1658 \pm 8$ \\
\hline \multirow{4}{*}{ Phase II } & Negrón & $1675 \pm 11$ \\
\cline { 2 - 3 } & Gorgaberos & $1681 \pm 14$ \\
\cline { 2 - 3 } & Carbajal & $1708 \pm 8$ \\
\cline { 2 - 3 } & La Cubilla & $1717 \pm 6$ \\
\hline \multirow{3}{*}{ Phase III } & Gorgaberos & $1756 \pm 6$ \\
\cline { 2 - 3 } & Carbajal & $1761 \pm 5$ \\
\cline { 2 - 3 } & Peña Castillo & $1758 \pm 7$ \\
\hline
\end{tabular}

moved to the south, following the Del Puerto River Valley.

From the Vega de Gorgaberos polje another small transfluent glacier generated at the foot of the crest of Peña Castillo and joined the main glacier tongue. The northern front of the main tongue from the Vega de Gorgaberos polje (which was the main area of ice accumulation) was located only $1.5 \mathrm{~km}$ to the north of the Vega de Gorgaberos during the maximum glacier advance, while the glacial ice reached more than $4 \mathrm{~km}$ to the southern front as a result of the afore mentioned transfluences, following the existing Del Puerto River Valley. The equilibrium line altitude during this maximum glacial advance was situated at $1636 \pm 15 \mathrm{~m}$, according to glacier ice reconstruction (Fig. 4; Tab. 1).

\section{GLACIAL LANDFORMS DURING THE RETREAT PHASES, PROGLACIAL SEDIMENTS AND POSTGLACIAL KARSTIC DYNAMICS}

In a second glacial stage, ice thickness decreased and the distinct tongues were disconnected from each other. ELA ascended to 1675 to $1717 \mathrm{~m}$ (Tab. 1) depending on the orientation and characteristics of each glacier. In the Vega de Gorgaberos polje, this phase is marked by a set of moraine arcs (Fig. 3B) indicating several periods of glacier stabilization during its retreat. The ice passage through the Los Navares Pass had disappeared, and the ice tongue flowing from the boundary with Asturias was stabilized at the foot of Negrón peak.

From the eastern-north face of Peña Castillo, a 1-kilometer-long glacier persisted in this retreat phase. This glacier formed a set of staggered moraines (located at $1460 \mathrm{~m}, 1485 \mathrm{~m}$ and $1510 \mathrm{~m}$ a.s.l., Fig. 3D) indicating successive phases of stabilization of the glacier front during the ice retreat. The lowest moraine dammed the Del Puerto River Valley, generating a lake (now a peatbog) in Campolamoso area. The moraines are composed only by limestone blocks and boulders and fine material from the crest of Peña Castillo, which shows this was the origin of the ice. They include sinkholes on their surface indicating the karstification of the bedrock (Fig. 3E). The lower moraine has 4 aligned sinks and a ponor through which a stream drains this side of the Del Puerto River Valley.

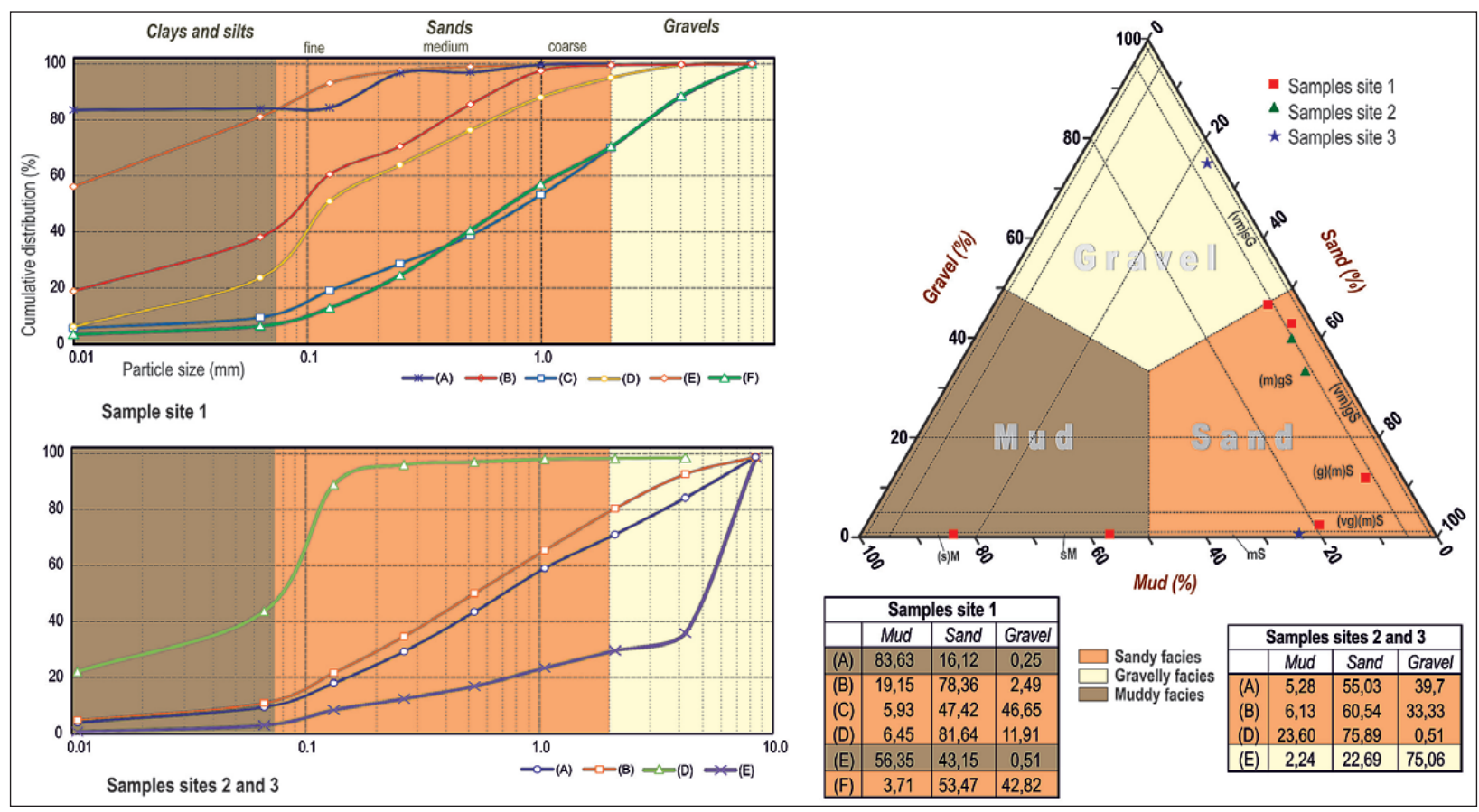

Fig. 5: Sedimentological analysis of the Vega del Panazal plain showing the sample sites, six samples (E, $C, F, D, A, B)$ in the meander site, and four $(A, B, D, E)$ in the confluence and spring sites. 
In the north-face of the highest areas of the Sierra de los Grajos, at the foot of the subvertical walls, small moraines indicated a last glacial stage, with the ELA situated at $\approx 1760 \mathrm{~m}$ (Tab. 1) and very small glaciers restricted to topographic favourable areas (Fig. 4).

Sediments (gravel, sand and fines) from glacier melting formed an extensive proglacial plain $\left(1.5 \mathrm{~km}^{2}\right)$ filling the Vega del Panazal depression. In this site more than $12 \mathrm{~m}$ thick sediment accumulated at the western margin of the sandur. There are no remnants of glacial origin in the Vega del Panazal (Fig. 3F) despite the relative high altitude and flat morphology bounded by steep slopes that are similar to other U-shaped glacial valleys in the Cantabrian Mountains. Moraines and some large erratics are only present in the upper part of the Vega del Panazal at an elevation of $1370 \mathrm{~m}$ a.s.l., corresponding with the glacier front. That location is approximately 500 $m$ downstream from the confluence of Del Puerto and Las Rozas Rivers.

Morphologically, the Vega del Panazal represents a depression created by differential erosion in Paleozoic shale. The Vega del Panazal is also a terrace level with a very gentle slope of only $1.5 \%$ to the WSW and corresponds to the filling of the depression during the local
Last Glacial Maximum. The terrace has greater continuity and extension on the left side than on the right, which is narrower and irregular due to the presence of abandoned terraces for agricultural use. The river has eroded another level beneath that fill level, approximately $10 \mathrm{~m}$ below the main upper surface of the depression. This derived level is particularly observed in the western part of the Vega del Panazal.

The sediment that fill the bottom of the Vega del Panazal (the thickness of the sediments is more than 10 $\mathrm{m}$ in the meander where 6 of the samples were collected) contains several stratifications of gravel and sand that alternate with silt and clay (massive, or very clear laminations) with different shades of colour. These characteristics and their grain size make it possible to attribute it a fluvioglacial origin. The samples indicate that there were sufficient water for mobilizing abundant sand and gravel interspersed with small, low-energy episodes with contributions of fine sediment. In general, the grain sizes of the detrital sediments of the Vega del Panazal are predominantly small (sand, gravel, Fig. 5), except for in the existing channel of the Del Puerto River, and the grain size of the sediments decreases from west to east.

\section{DISCUSSION}

The extensive outcrops of Paleozoic limestone in the Cantabrian Mountains are characterized by intense karstification (González-Gutiérrez et al. 2017). The dissolution of calcareous rocks had been a relevant process over long periods of time, as occurs in Las Médulas World Heritage Site (located $85 \mathrm{~km}$ to the southwest), where karstic landforms are fossilized by Miocene sediments (Redondo Vega et al. 2015). Paradoxically, karstification has allowed the preservation of extensive paleo-surfaces because the underground drainage has largely protected the surfaces from the fluvial erosion. These surfaces often indicate a long morphogenesis and are the remnants of ancient morphostructures. They are the consequence of the progressive adjustment of the river network to the uplifted areas that were generated from the ancient eroded Paleozoic massif during the Alpine tectonics (GonzálezGutiérrez et al. 2017).

The long morphogenetic evolution of the Cantabrian Mountains, characterized by differential erosion processes, has favoured the development of cohesive rock outcrops alternating with valleys incised into incohesive rocks (González-Gutiérrez et al. 2017). In our study area, due to differential erosion there are areas with gentle slopes at different altitudes (e.g. Vega del Panazal and Vega de Gorgaberos).

Some pre-glacial landforms were highly favourable to ice accumulation during the Pleistocene, much more than one would expect from their modest altitude, $1857 \mathrm{~m}$ a.s.l., especially when this massif is compared to the higher nearby mountain massifs (e.g., Peña Ubiña, with an altitude of $2411 \mathrm{~m}$ a.s.l.). Therefore, a key factor to understanding the glaciation on the southern side of the Cantabrian Mountains (Jalut et al. 2010; SantosGonzález et al. 2013b) is the presence of high and extensive paleo-surfaces that act as glacial accumulation zones, even in areas without cirques, as in the case of the Sierra de los Grajos. This phenomenon explains why Paleozoic limestone in the study area indicates obvious signs of karstification and glaciation (Fig. 3).

According to glacial ice reconstruction, ELA was situated at $1636 \pm 15 \mathrm{~m}$ during the maximum glacial advance. This altitude agrees with paleo-ELA reconstructions in the Cantabrian Mountains (Santos-González et al. 2013a; Serrano et al. 2013; Rodríguez-Rodríguez et al. 2015), where great differences occur depending on regional temperature and precipitation variations. In the 
case of the Sierra de los Grajos, ice accumulation was restricted to the favourable topographic areas, as the Vega de Gorgaberos polje and isolated north face slopes.

The moraines in the Sierra de los Grajos show the occurrence of many glacial stages that should be correlated with previous researches on glacial chronology in the Cantabrian Mountains (Jalut et al. 2010; Frochoso et al. 2013; Jiménez-Sánchez et al. 2013; Serrano et al. 2013; Rodríguez-Rodríguez et al. 2016; Ruiz-Fernández et al. 2016), that show a local glacial maximum previous to the global Last Glacial Maximum.

In the Cantabrian Mountains, there are other massifs with the same rocks and altitudes, such as the Fresneda massif (González Gutiérrez 2001; FernándezMartínez et al. 2009) and the Sancenas massif (Fernández-Martínez et al. 2009; González-Gutiérrez et al. 2017). They also show well-developed karst landforms together with glacial landforms. This is the case of the glaciated and intensely karstified surfaces and poljes of the Sancenas massif (Fernández-Martínez et al. 2009; GonzálezGutiérrez et al. 2017); this site maintains characteristics that are common with the study area.

The Paleozoic limestone that form the Sierra de los Grajos exhibits intense karstification that results in rocky outcrops dotted with sinkholes with vertical walls and chasms in environments located at 1750-1850 m a.s.l. Sinkholes, uvalas and poljes with irregular boundaries are common below that level (1550-1650 m a.s.l.). Some of these closed depressions are often filled with the clay remnants from the dissolution of limestone and occasional glacial till.

The Vega de Gorgaberos is a karstic polje (Fig. 3B) that favoured the accumulation of glacier ice. The ponors and other small intramorainic sinkholes have preserved the moraines from post-glacial erosion (Fig. 3D) because the filling of the karst with glacial sediment (Johnson \& Stieglizt 1990) occurs without altering the hydrological function of the karst landforms (Ford 1983).
Glacier development was restricted to the upper areas, so in the lower areas karst water circulation was never interrupted (Ford 1983; Smart \& Ford 1983). In contrast, the subglacial meltwater had to have influenced the development of the karst (Johnson \& Stieglizt 1990) by reactivating karstification upon rapidly increasing the amount of water in the system (Smart 2004; Adamson et al. 2014). Unfortunately, there is no known access to the underground cavities of the massif where these processes could be reflected in the ducts.

The aligned sinks located between the moraines and the isolated sinkholes (suffusion depressions; Ford 1979; Smart \& Ford 1983; Smart 2004) on both the moraines and undifferentiated till in the Vega de Gorgaberos and in the eastern valley of Peña Castillo, correspond to postglacial glaciokarstic landforms and indicate the continued sinking by dissolution of the limestone substrate (Fig. 3E). The subterranean drainage has influenced their preservation (Žebre \& Stepišnik 2015), although their morphology and volumes have been notably diminished by the dissolution of limestone.

This has been observed in other parts of the Cantabrian Mountains, as occur in moraines of the valley of Viadangos de Arbás (Redondo Vega \& Santos González 2011) and in rock glaciers of the Sierra Sentiles and Fuentes de Invierno (González-Gutiérrez et al. 2016).

An outwash-plain developed downstream from the front of the main glacier, with successive depositional aggradation events (formation of sandur) followed by episodes of fluvial incision that generated terraces in the Vega del Panazal (Fig. 3F). The diversion of waters to the karstic network resulted in their control over the fluvioglacial sedimentary processes and in the preservation of these sediments (Adamson et al. 2014) by drastically reducing circulating flows and maintaining flow only from non-karstified areas.

\section{CONCLUSIONS}

The Sierra de los Grajos, a small massif of the Cantabrian Mountains, constitutes an extraordinary example of convergence of karstic and glacial processes.

The karstification processes on high paleo-surfaces favoured glacier dynamics in the Sierra de los Grajos in a double meaning:

i) it made possible the accumulation of ice and its persistence and, in addition, the deviation of water into the karst; forms.

ii) it allowed the conservation of overlapping glacial

Besides, deglaciation has played a fundamental role in several ways:

i) the prevalence of chemical dissolution over other surface processes, so we can consider karstification as the main geomorphological factor;

ii) the restoration of the karst dynamics and preglacial underground drainage of most of the study area, es- 
sential to preserve glacial accumulation landforms. The poor subaerial water circulation results in less active paraglacial processes, allowing for a better preservation of glacial landforms than in other Cantabrian valleys;

iii) the degradation of glacial landforms due to karstic processes, as evidenced by the development of sinkholes (suffusion depressions) in moraines;

iv) the rapid degradation and disappearance of the detailed erosive subglacial forms (polished surfaces, grooves) when they remained under subaerial conditions subject to postglacial dissolution;

v) the generation of an extensive proglacial plain $\left(1.5 \mathrm{~km}^{2}\right)$ filling a preglacial depression in the outermost margin of the main glacier.

Definitively, the process of superimposing glacial dynamics on the karst terrain has generated a mixed morphology in which the dissolution of limestone and the drainage of runoff waters into the karst occur between the moraines and the deposits of subglacial till, resulting in the development of glaciokarstic landforms. These landforms include: areas with karstic and glacial landforms, moraines with sinkholes, moraines with ponor, siliceous erratic boulders over limestone, moraines with any postglacial fluvial erosion, sinkholes and chasms occasionally with glacial sediments and an outwash-plain in a karstic environment.

More effort concerning the relationships between glacial and karstic landforms is needed to understand in greater detail the glaciokarstic landforms. The Sierra de los Grajos is a small but extraordinary example of these forms, although there are also other massifs with glaciokarstic landforms in the Cantabrian Mountains, so more studies about this kind of forms should be developed in the near future.

\section{ACKNOWLEDGMENTS}

This work is partially supported by the projects MEDLANT (Depositional and geochemical dynamics of MEDiterranean Watershed-LAke Systems during the ANThropocene: disentangling human and climate forcings) (CGL2016-76215-R) and ESPAS (Scenarios of water and sediment yield from land cover and land- use changes: effects of active and passive management) (CGL2015-65569-R MINECO-FEDER).

The comments and suggestions of two anonymous reviewers have improved the first version of the manuscript.

\section{REFERENCES}

Adamson, K.R., Woodward J.C. \& P.D. Hughes, 2014: Glaciers and rivers: Pleistocene uncoupling in a Mediterranean mountain karst.- Quaternary Science Review, 94, 28-43. DOI: https://doi.org/10.1016/j. quascirev.2014.04.016.

Alonso, J.L., Marcos, A. \& A. Suárez, 2009: Paleogeographic inversion resulting from large out of sequence breaching thrusts: the León Fault (Cantabrian Zone, NW Iberia). A new picture of the external Variscan Thrust Belt in the Ibero-Armorican Arc.Geologica Acta, 7, 4, 451-473. DOI: https://doi. org/10.1344/105.000001449.

Alonso Herrero, E., Fernández Martínez, E., Rodríguez Fernández, L.R. \& R. Matías Rodríguez, 2004: Guía geológica visual del León.- Editorial Celarayn, pp. 275, León.
Benn, D.I. \& A.M.D. Gemmell, 1997: Calculating equilibrium-line altitudes of former glaciers by the balance ratio method: a new computer spreadsheet.Glacial Geology and Geomorphology (http://ggg. qub.ac.uk/ggg/full/1997/tn011997/tn01.html).

Bodgdan, G. \& L. Leszek, 1999: Glaciokarst of subalpine and alpine zone of the Mala làka Valley, Tatra Mts., Poland.- Acta Carsologica, 28, 1, 71-86.

van den Bosch, W.J., 1969: Geology of the Luna-Sil Region, Cantabrian Mountains (NW Spain).- Leidse Geologische Mededelingen, 44, 137-225.

Blott, S.J. \& K. Pye, 2012: Particle size scales and classification of sediments types based on particle size distributions: Review and recommended procedures.Sedimentology, 59, 7, 2017-2096. DOI: https://doi. org/10.1111/j.1365-3091.2012.01335.x. 
Fernández-Martínez, E., Fuertes Gutiérrez, I., Alonso Herrero, E., Redondo Vega, J.M, Cortizo Álvarez, J., Gómez Villar, A., Santos González, J., Herrero Hernández, A. \& R.B. González Gutiérrez, 2009: Lugares de interés geológico. León. DVD.- Fundación Patrimonio Natural, Junta de Castilla y León, León.

Ford, D.C., 1979: A review of Alpine karst in the Southern Rocky Mountains of Canada.- Bulletin of the National Speleological Society, 41, 3, 53-65.

Ford, D.C., 1983: Effects of glaciations upon karst aquifers in Canada.- Journal of Hydrology, 61, 1-3, 149-158. DOI: https://doi.org/10.1016/0022-1694(83)90240-8.

Frochoso, M., González-Pellejero, R. \& F. Allende, 2013: Pleistocene glacial morphology and timing of Last Glacial Cycle in Cantabrian Mountains (Northern Spain): new chronological data from the Asón area.- Open Geosciences, 5, 1, 12-27. DOI: https:// doi.org/10.2478/s13533-012-0117-8

Furbish, D.J. \& J.T. Andrews, 1984: The use of hypsometry to indicate long-term stability and response of valley glaciers to changes in mass transfer.- Journal of Glaciology, 30, 105, 199-211.

Gams, I., 2005. Tectonics impact on poljes and minor basins (case studies of Dinaric karst).- Acta Carsologica, 34, 1, 25-41. DOI: https://doi.org/10.3986/ ac.v34i1.277.

García de Celis, A., 1997: El relieve de la montaña occidental de León.- Universidad de Valladolid, Serie Geografía, 14, pp. 291, Valladolid.

García de Celis, A. \& L.C. Martínez Fernández, 2002: Morfología glaciar de las montañas de la cuenca alta de los ríos Sil, Omaña, Luna y Bernesga: revisión y nuevos datos (Montaña Occidental de León).- In: Redondo Vega, J.M. et al. (eds.) El modelado de origen glaciar en las montañas leonesas, Universidad de León, Secretariado de Publicaciones y Medios Audiovisuales, pp. 137-193, León.

Goldie, H.S., 2006: Mature intermediate-stage surface karst landforms in NW England and their relations to glacial erosion.- In: Kiss, A. et al. (eds.) Landscape, Environment and Society, Szeged University Press, Hungary, pp. 225-238, Szeged.

Gómez-Villar, A., Santos-González, J., González-Gutiérrez, R.B. \& J.M. Redondo-Vega, 2015: Glacial cirques in the southern side of the Cantabrian Mountains of southwestern Europe.- Geografiska Annaler: Series A, Physical Geography, 97, 4, 633-651. DOI: https://doi.org/10.1111/geoa.12104.
González Gutiérrez, R.B., 2001: El relieve de los valles del Torío y Curueño (Montaña Cantábrica Leonesa).$\mathrm{PhD}$ thesis. Universidad de León, Secretariado de Publicaciones y Medios Audiovisuales, Serie Tesis Doctorales, León, pp. 267.

González-Gutiérrez, R.B., Santos-González, J., Santos, J.A.B., Redondo-Vega, J.M., Gómez-Villar, A. \& J.R. Irwin, 2016: Macro-fabric analysis in relict rock glaciers Cantabrian Mountains, NW Spain.- In: Instituto Politécnico de Bragança (ed.) I International Conference on Research for Sustainable Development in Mountain Regions: Book of Abstracts, $3^{\text {rd }}-7^{\text {th }}$ October 2016, Bragança. Centro de Investigção de Montanha (CIMO), 124, Bragança.

González-Gutiérrez, R.B., Santos-González, J., GómezVillar, A., Redondo-Vega, J.M. \& I. Prieto-Sarro, 2017: Geomorphology of the Curueño River Headwaters, Cantabrian Mountains: (NW Spain).- Journal of Maps, 13, 2, 382-394. DOI: https://doi.org/10 $.1080 / 17445647.2017 .1316217$

González Trueba, J.J., 2007: Geomorfología del Macizo Central del Parque Nacional Picos de Europa. Organismo autónomo de Parques Nacionales, pp. 231, Madrid.

Hughes, P.D., Woodward, J.C., van Calsteren, P.C., Thomas, L.E. \& K.R. Adamson, 2010: Pleistocene ice caps on the coastal mountains of the Adriatic Sea.- Quaternary Science Reviews, 29, 27-28, 3690-3708. DOI: https://doi.org/10.1016/j. quascirev.2010.06.032.

Jalut, G., Turu i Michels, V., Dedoubat, J.J., Otto, T., Ezquerra, J., Fontugne, M., Belet, J.M., Bonnet, L., García de Celis, A., Redondo-Vega, J.M., Vidal-Romaní, J.R. \& L. Santos, 2010: Palaeoenvironmental studies in NW Iberia (Cantabrian range): Vegetation history and synthetic approach of the last deglaciation phases in the western Mediterranean.Palaeogeography, Palaeoclimatoloy, Palaeoecology, 297, 2, 330-350. DOI: https://doi.org/10.1016/j. palaeo.2010.08.012.

Jiménez-Sánchez, J., Rodríguez-Rodríguez, J., GarcíaRuiz, J.M., Domínguez-Cuesta, M.J., Farias, P., Valero-Garcés, B., Moreno, A., Rico, M. \& M. Valcárcel, 2013: A review of glacial geomorphology and chronology in northern Spain: Timing and regional variability during the last glacial cycle.Geomorphology, 196, 15, 50-64. DOI: https://doi. org/10.1016/j.geomorph.2012.06.009.

Johnson, S.B. \& R.D. Stieglizt, 1990: Karst features of a glaciated dolomite peninsula, Door County, Wisconsin.- Geomorphology, 4, 1, 37-54. DOI: https:// doi.org/10.1016/0169-555X(90)90025-L. 
Lepirica, A., 2008: Geomorphological characteristics of the Massif Prenj.- Acta Carsologica, 37, 2-3, 307-329.

Osmaston, H., 2005: Estimates of glacier equilibrium line altitudes by the area $\times$ altitude, the area $\times$ altitude balance ratio and the area $\times$ altitude balance index methods and their validation.- Quaternary International, 138-139, 22-31. DOI: https://doi. org/10.1016/j.quaint.2005.02.004.

Rea, B.R., 2009: Defining modern day area-altitude balance ratios (AABRs) and their use in glacier-climate reconstructions.- Quaternary Science Reviews, 28, 3-4, 237-248. DOI: https://doi.org/10.1016/j. quascirev.2008.10.011.

Redondo Vega, J.M. \& J. Santos González, 2011: La construcción del relieve del Alto Bernesga.- In: Fernández-Martínez, E. (eds.) Guía del patrimonio Geológico del Alto Bernesga. Ilmo, Ayto, La Pola de Gordón, pp. 89-145, León.

Redondo-Vega, J.M., Alonso-Herrero, E., SantosGonzález, J., González-Gutiérrez, R.B. \& A. GómezVillar, 2015: La Balouta exhumed karst: a Roman gold-mine-derived landscape within the Las Médulas UNESCO World Heritage Site (Spain).- International Journal of Speleology, 43, 3, 267-276. DOI: https://doi.org/10.5038/1827-806X.44.3.5.

Rodríguez Pérez, C., 2009: Geomorfología de la Montaña Astur-Leonesa entre los puertos de Ventana y de Somiedo.- PhD thesis. Department of Geography, Oviedo University, pp. 365.

Rodríguez-Rodríguez, L., Jiménez-Sánchez, M., Domínguez-Cuesta, M. J. \& A. Aranburu, 2015: Research history on glacial geomorphology and geochronology of the Cantabrian Mountains, north Iberia $\left(43-42^{\circ} \mathrm{N} / 7-2^{\circ} \mathrm{W}\right) .-$ Quaternary International, 364, 6-21. DOI: https://dx.doi.org/10.1016/j. quaint.2014.06.007.

Rodríguez-Rodríguez, L., Jiménez-Sánchez, M., Domínguez-Cuesta, M.J., Rinterknecht, V., Pallàs, R. \& D. Bourlès, 2016: Chronology of glaciations in the Cantabrian Mountains (NW Iberia) during the Last Glacial Cycle based on in situ-produced ${ }^{10} \mathrm{Be}$.Quaternary Science Reviews, 138, 31-48. DOI: https://doi.org/10.1016/j.quascirev.2016.02.027.

Ruiz-Fernández, J., Oliva, M., Cruces, A., Lopes, V., Freitas, M.C., Andrade, C., García-Hernández, C., López-Sáez, J.A. \& M. Geraldes, 2016: Environmental evolution in the Picos de Europa (Cantabrian Mountains, SW Europe) since the Last Glaciation.Quaternary Science Reviews, 138, 87-104. DOI: https://doi.org/10.1016/j.quascirev.2016.03.002.
Santos-González, J., Redondo-Vega, J.M., GonzálezGutiérrez, R.B. \& A. Gómez-Villar, 2013a: Applying the AABR method to reconstruct equilibrium-line altitudes from the last glacial maximum in the Cantabrian Mountains (SW Europe).- Palaeogeography, Palaeoclimatology, Palaeoecology, 387, 185-199. DOI: https://dx.doi.org/10.1016/j. palaeo.2013.07.025.

Santos-González, J., Santos, J.A., González-Gutiérrez, R.B., Redondo-Vega, J.M. \& A. Gómez-Villar, 2013b: Till fabric and grain-size analysis of glacial sequences in the Upper Sil River Basin, Cantabrian Mountains, NW Spain.- Physical Geography, 34, 6, 471-490. DOI: https://doi.org/10.1080/02723646.2 013.855989.

Serrano, E., González-Trueba, J.J. \& M. GonzálezGarcía, 2012. Mountain glaciation and paleoclimate reconstruction in the Picos de Europa (Iberian Peninsula, SW Europe).- Quaternary Research, 78, 303-314. DOI: https://dx.doig.org/10.1016/j. yqres.2012.05.016.

Serrano, E., González-Trueba, J.J., Pellitero, R., González-García, M. \& M. Gómez-Lende, 2013: Quaternary glacial evolution in the Central Cantabrian Mountains (Northern Spain).- Geomorphology, 196, 65-82. DOI: https://dx.doi.org/10.1016/j. geomorph.2012.05.001.

Smart, C., 2004: Glacierized and Glaciated karst, In: Gunn, J. (ed.) Encyclopedia of caves and karst science. Fitzroy Dearborn, pp. 804-809, New York.

Smart, C.C. \& D.C. Ford, 1983: The Castleguard karst, Main Ranges, Canadian Rocky Mountains.-Journal of Hydrology, 61, 1-3, 193-197. DOI: https:// dx.doi.org/10.1016/0022-1694(83)90247-0.

Stepišnik, U., 2014: Geomorphological properties of the Krasno Polje, Northern Velebit, Croatia.- RAZPRAVE, 41, 101-115.

Suárez Rodríguez, A., Toyos, J.M., López Díez, F., Heredia, N., Rodríguez Fernández, L.R. \& G. Gutiérrez Alonso (IGME), 1989: Mapa Geológico de España, Los Barrios de Luna, 102. 1 : 50000.- Madrid.

Telbisz, T., Mari, L. \& L. Szabó, 2011: Geomorphological characteristics of the italian side of Canin Massif (Julian Alps) using digital terrain analysis and field observations.- Acta Carsologica, 40, 2, 255-266.

Wentworth, C., 1922: A scale of grade on class terms for clastic sediments.- The Journal of Geology, 30, 5, 377-392. 
Žebre, M. \& U. Stepišnik, 2015: Glaciokarst landforms and processes of the southern Dinaric Alps.Earth Surface Processes and Landforms, 40, 11, 1493-1505. DOI: https://doi.org/10.1002/esp.3731
Žebre, M., Stepišnik U., Colucci, R.R., Forte, E. \& G. Monegato, 2016: Evolution of a karst polje influenced by glaciation: The Gomance piedmont polje (northern Dinaric Alps).- Geomorphology, 257, 143-154. DOI: https://doi.org/10.1016/j. geomorph.2016.01.005 